\title{
Д.С. Ибраева
}

докторант $\mathrm{PhD}$, Казахский национальный университет имени аль-Фараби, Казахстан, г. Алматы, e-mail: ibrayeva.danara@gmail.com

\section{ИЗУЧЕНИЕ ЖАНРА ХУАОЖЕСТВЕННОЙ АВТОБИОГРАФИИ В ВУЗЕ (НА ПРИМЕРЕ РОМАНА Г.К. БЕАЬГЕРА «АОМ СКИТААЬЦА»)}

Аннотация. В статье рассматриваются особенности изучения автобиографических художественных произведений в вузе на примере романа Г.К. Бельгера "Аом скитальца». В ходе анализа данного произведения в вузовской аудитории следует учитывать тот факт, что художественная автобиография подвергает эпизоды реальной автобиографии поэтической обработке и преобразует конкретное достоверное событие в художественный факт.

В статье формулируется вывод о том, что художественная автобиография является особым жанром в митературе. Автор статьи полагает, что к такому жанру следует отвести произведение, основанное на документальных фактах из жизни автора произведения, которые превращаются в художественные образы и становятся не только субъектом, но и объектом изображения. Изложенные выше литературоведческие положения стали основой для изучения романа Г.К. Бельгера "Аом скитальца» в вузе. Методическая модель анализа романа "Аом скитальца» предполагает выявление признаков автобиографической художественной прозы на уровне сюжета, композиции, хронотопа, системы образов. Помимо традиционного разбора произведения, студентам была предложена таблица, визуально отражающая особенности жанровой природы митературно-художественной автобиографии. В апробации методики в опытно-педагогической работе приняли участие 35 студентов филологических специальностей.

Кмючевые слова: автобиографизм, художественность, документализм, жанр, образ, эвристический метод, эвристическая беседа, интерактивное занятие, пообразный анализ, Г.К. Бельгер, «Аом скитальца».

\author{
D.S. Ibrayeva \\ PhD doctoral of Al-Farabi Kazakh National University, Kazakhstan, Almaty, \\ e-mail: ibrayeva.danara@gmail.com \\ The Study of the Genre of Artistic Autobiography at the University \\ (on the Example of the Novel by G.K. Belger "House of the Wanderer")
}

\begin{abstract}
The article discusses the features of the study of autobiographical art works in in higher schooll on the example of the novel by G.K. Belger "House of the wanderer." When analyzing this work in a university audience, one should take into account the fact that artistic autobiography exposes the episodes of a real autobiography to poetic processing and converts a specific reliable event into an artistic fact. If in autobiographical works, some writers describe everythin that happened around, others repel from inside spiritual existence and tie up to researching of own thoughts and souls, through this they try to reflect the sate of mankind in general.

The article concludes that fiction autobiography is a special genre in literature. The author of the article believes that a work based on documentary facts from the life of its author, which turns into artistic images and becomes not only a subject, but also an object of the image, should be assigned to such a genre. The above literary propositions became the basis for the study of the novel by G.K. Belger "House of the wanderer" at the university. The methodological model of the analysis of the novel "The Wanderer's House" involves identifying signs of autobiographical fiction at the level of plot, composition, chronotope, and system of images.

In addition to the traditional analysis of the work, the students were offered a table that visually reflects the features of the genre nature of literary and artistic autobiography. 35 students of philological specialties took part in approbation of a technique in experimental pedagogical work.

Key words: autobiography, artistry, documentary, genre, image, heuristic method, heuristic conversation, interactive lesson, a kind of analysis, G.K. Belger, "House of the Wanderer."
\end{abstract}




\title{
А.С. Ибраева \\ $\mathrm{PhD}$ докторанты, әл-Фараби атындағы Қазақ, ұлттық университеті, Қазақстан, Алматы қ., e-mail: ibrayeva.danara@gmail.com \\ Жоғары білім берудегі көркем автобиография жанрын оқыту \\ (Г.К. Бельгердің «Кезбе үйі» романының негізінде)
}

\begin{abstract}
Аңдатпа. Мақалада жоғары білім берудегі автобиографиялық көркем шығармаларының ерекшеліктерін оқыту Г.К. Бельгер «Кезбе үйі» романының негізінде қарастырылады. Сабақ барысында жұмысты талдай отырып, көркем өмірбаян нақты өмірбаян эпизодтарын поэтикалық өңдеуге ұшырататындығын және белгілі бір сенімді оқиғаны көркемдік фактке айналдыратындығын ескерген жөн. Егер автобиографиялық жұмыстарда кейбір жазушылар айналада болып жатқан барлық нәрсені сипаттайтын болса, басқалары ішкі рухани өмірден бастау алады және өздерінің ойларын және өз жандарын зерттеуге тырысады, сол арқылы адамзаттың тағдырын көрсетуге тырысады.

Мақалада көркем әдебиеттің өмірбаяны әдебиеттегі ерекше жанр екендігі айтылады. Мақала авторы көркем образдарға айналатын және тек объект ғана емес, сонымен бірге объектінің объектісіне айналатын автордың өмірінен алынған деректі фактілерге негізделген туынды осындай жанрға берілуі керек деп санайды. Жоғарыда келтірілген әдеби ұсыныстар Г.К.Бельгер романын зерттеуге негіз болды. «Кезбе үйі» романын талдаудың әдіснамалық моделі сюжет, композиция, хронотоп және бейнелер жүйесі деңгейіндегі автобиографиялық көркемАік белгілерді анықтаудан тұрады. Студенттерге дәстүрлі түрдегі шығарма талдаудан басқа әдебикөркем өмірбаянның жанрлық табиғатын бейнелі танытатын кесте ұсынылды. Тәжірибелікпедагогикалық жұмыстың әдістемесін байқаудан өткізуге филологиялық мамандықтардың 35 студенті қатысты.
\end{abstract}

Түйін сөздер: автобиография, көркемдік, деректі, жанр, образ, эвристикалық әдіс, эвристикалық әңгіме, интерактивті сабақ, та^даудың бір түрі, Г.К. Бельгер, «Кезбе үйі».

\section{Введение}

В настоящее время в нашей стране происходят процессы обновления образования. Разрабатываются новые подходы к обучению. В методике преподавания литературы также наблюдается активный творческий поиск. Главная задача методической науки заключается в том, чтобы разработать эффективные пути и средства обучения литературе. Особую актуальность приобретает методическое освоение современной русской автобиографической литературы Казахстана, в которой подняты важные для глубокого осмысления отечественной истории проблемы. Приобщение студентов к художественным достижениям и мировоззренческому пространству русской казахстанской литературы необходимо для их эстетического и патриотического воспитания.

\section{Методология и методы исследования}

Теоретико-концептуальную основу нашего исследования составила методология системного изучения художественного текста с позиций теории и истории литературы, методики преподавания литературы в вузе. В статье использованы методы литературоведческой социологии, текстологического исследования художественного материала, стилистического анализа произведения с целью выявления жанровой спец- ифики и других художественных особенностей автобиографического текста. Привлечены методы эвристического и проблемного обучения студентов.

\section{Обзор литературы}

Автобиографизм - это одна из форм исторической памяти цивилизаций, основа духовной связи поколений. Автобиографизм как художественный принцип применялся писателями в разной степени. Одни авторы многое из реальной жизни включали в свои тексты, другие - только отдельные факты бытового характера. В определенной степени это можно объяснить изменившимися историческими реалиями, потребовавшими другого уровня оценки происходящего, чем прежде. Это обстоятельство подмечено в литературоведении. «Документальная проза будущего и есть эмоционально окрашенный, окрашенный душой и кровью мемуарный документ, где все - документ и в то же время представляет эмоциональную прозу...» (Barahov, 1985).

В работе Н.Л. Лейдермана, М.Н. Липовецкого «Современная русская литература. 1950-1990е годы» описан сформировавшийся в литературе последних десятилетий прошлого века «новый автобиографизм» (Lejderman, 1997; Lipoveckij, 1997). Автобиографизм понимается современными исследователями как трансформация ав- 
тором «жизненного материала» в направлении своей экзистенциальной сферы, своего эмоционального комплекса и видения человека; в литературно-художественном произведении такое понимание автобиографизма реализуется указанием субъекта речи на автобиографическую основу повествования (Bronskaja, 2001; Bol'shev, 2002; Badikov, 2007).

Основным критерием определения текста как автобиографии является наличие в нем описания наполняющих жизнь человека конкретных событий, изложенных им самим. Согласно определению Ф. Лежэна, «автобиография является повествовательным текстом с ретроспективной установкой, в котором реальная личность рассказывает о собственном бытии, и притом ударение ставит на свою личную жизнь, особенно историю становления своей личности» (Lezhjen, 1973).

Весьма продуктивной представляется концепция, сформулированная в работе М. Медарич: «Автобиографизмом мы можем назвать стилистически маркированный литературный прием, представляющий собой эхо жанра автобиографии; он появляется в текстах, которые сами по себе не являются автобиографией, не писались и не воспринимались как автобиографии». Тонко дифференцируя смежные понятия, автор данной работы далее говорит: «Автобиография включает в качестве предмета описания личность в пространстве и времени, личность, являющуюся одновременно субъектом и объектом описания. Автобиографизм как отзвук автобиографии можно искать лишь там, где автор текста о себе определен и как принципиально возможный объект историографии (конкретная эмпирическая личность во времени и пространстве), и одновременно как субъект самопознавательных дисциплин, философии и психологии (трансцендентная личность)» (Medarich, 1998).

Казахстанские ученые выделяют в качестве одного из основных признаков принадлежности произведений к автобиографическому жанру ссылки на документальные материалы. При этом указывается на существование индивидуальных пристрастий авторов, отличия в процессе создания художественной картины мира, основанной на реальных событиях. Исследователи считают, что именно для произведений с элементами автобиографизма характерна структура образа героя с преобладанием элементов «внутреннего» плана при существовании элементов «внешнего» плана, обусловленных влиянием идеологических факторов (Nurpeisov, 2001; Salhanova, 2016; Safronova, 2009, Temirbolat, 2011).
Проблема автобиографизма в литературе продолжает оставаться неоднозначной и требует дальнейшей разработки. Несмотря на это, необходимо активно включать в процесс обучения в вузе литературные произведения русских казахстанских писателей, которые применяли принцип автобиографизма в своем творчестве. Творчество Г.К. Бельгера еще не стало предметом активного методического освоения. Но появились работы подобного профиля. Назовем статью А.С. Демченко, в которой представлена методика анализа категории архетипа «Дом» в романах Г.К. Бельгера (Demchenko, 2018). Однако в выбранном нами аспекте проза Г.К. Бельгера еще не изучалась в методике преподавания русской литературы.

Методика изучения русской казахстанской прозы должна опираться на наработки эвристического (Hutorskoj, 2003) и проблемного обучения, которые способствуют развитию мышления студентов. В этом отношении продуктивна технология развивающего обучения, предполагающая систематическое взаимодействие педагога и студентов, активный поиск эффективных способов решения учебных задач посредством эвристического диалога. Данная технология основывается на теориях развивающего обучения (Zankov, 1990; Davydov, 1986; Bondarevskaya, 2000; Selevko, 2005).

\section{Результаты}

Анализ романа Г.К. Бельгера «Дом скитальца» был осуществлен на практическом занятии по дисциплине «История русской литературы Казахстана». Для успешного проведения анализа романа «Дом скитальца» необходимо предварительно сформировать у студентов исходные теоретические представления о жанре художественной автобиографии. Студенты должны знать, что основным критерием определения текста как автобиографии является наличие в нем описания конкретных событий, изложенных самим автором. Кроме того, выясняем, что в жанре автобиографии выделяются два подтипа: документальный и художественный.

Студенты должны понимать, что в документальной автобиографии повествование воспроизводит эмпирические факты, автор стремится передать реальные жизненные события с документальной точностью. На занятии формулируется вывод о том, что художественная автобиография представляет собой особый жанр в литературе. К такому жанру следует отвести произведение, основанное на документальных 
фактах из жизни писателя, которые превращаются в художественные образы и становятся не только субъектом, но и объектом изображения. Степень документальности или художественности автобиографического текста определяется уровнем отклонения созданного в произведении литературного образа от реального авторского облика. Внимание студентов акцентируется на том, что писатель при этом конструирует автобиографический образ как литературный портрет представителя эпохи, стремится представить свою личность как неотъемлемую часть общественного и исторического процесса.

Особенность художественной автобиографии заключается в том, что в ней эпизоды реальной автобиографии подвергаются поэтической обработке и конкретное достоверное событие преобразуется в художественный факт. В автобиографии такого типа вымышленные, воображаемые моменты жизни играют более значимую роль, чем документальные. Все указанные признаки художественной автобиографии присущи роману Г.К. Бельгера «Дом скитальца».

Кроме отмеченного выше, преподаватель формирует у студентов представления о жизни и творчестве Г.К. Бельгера. На занятии студенты выступают с заранее подготовленными сообщениями о жизни и творческом пути писателя, внесшего большой вклад в развитие современной казахстанской литературы. Выявляется транскультурный характер творчества Г.К. Бельгера, органично объединившего в своих произведенияХ казахскую, немецкую и русскую культуру.

Преподавателем формулируется целевая установка. Он объявляет студентам, что на занятии следует выявить и проанализировать особенности жанра художественной автобиографии на примере романа казахстанского писателя Герольда Бельгера «Дом скитальца». Кроме того, необходимо определить признаки автобиографической художественной прозы на уровне сюжета, композиции, хронотопа, системы образов произведения. Студенты должны понять, что взаимодействие элементов документализма и художественности составляют индивидуальный стиль писателя, определяют специфику его творчества. Все эти основные учебные задачи следует четко изложить, чтобы деятельность студентов приобрела целенаправленный характер.

После предварительной работы приступаем к анализу автобиографического характера произведения Г.К. Бельгера. Задаем студентам ключевой вопрос - В чем заключается автобиографичность романа Г. К. Бельгера «Дом скитальца»?
В результате обсуждения студенты приходят к выводу, что не только этот роман, но и большая часть его произведений автобиографична, так как в них сюжетно и композиционно соединились документальность и художественность, реальность и вымысел, философские размышления и искренние чувства.

Важно обратить внимание студентов на главные темы романов Г.К. Бельгера. Студенты отвечают, что в романах «Дом скитальца» и «Туюк су» сходятся воедино главные темы Г.К. Бельгера. Эти многоплановые произведения с разветвленными сюжетными линиями, обладающими своеобразной композицией, содержат новый уровень художественного документализма, так как в них отражены целые пласты истории (репрессии, война, трудовая армия, послевоенное время и современная действительность), пережитые самим автором.

Необходимо связать биографию Г.К. Бельгера с его ключевыми произведениями, чтобы у студентов сложилось целостное представление о его творчестве. Преподаватель задает студентам вопрос: «Как соотносится биография Герольда Бельгера и его литературное творчество»? Студенты утверждают, что биография писателя во многом совпадает с описанными им в литературных произведениях событиях. Писатель родился 28 октября 1934 года в городе Энгельсе, столице немецкого Поволжья. В 1941 году по указу Сталина он вместе с другими российскими немцами был депортирован в Казахстан. Г.К. Бельгер учился в казахской средней школе, затем окончил филологический факультет Казахского педагогического института, работал учителем русского языка и литературы, затем в литературном журнале. С 1964 года - писатель и переводчик. Бельгер отлично владел казахским языком и являлся знатоком казахской литературы, переводил книги с немецкого языка на казахский и русский. Особое место в его творчестве занимала публицистика, посвященная актуальным вопросам истории и современности. В творчестве Герольда Бельгера, писателя и переводчика, художественность и документальность образуют синтез, который давал возможность выразить личностное отношение к историческим событиям. В творчестве Герольда Бельгера нашли отражение историческое исследование и художественное воссоздание событий депортации немцев Поволжья в Центральную Азию во время второй мировой войны, их дальнейшая судьба, их интеграция в Казахстане. Он опубликовал книги и статьи на эту тему на русском, казахском и немецком языках. 
Следующий методический этап анализа автобиографичности прозы Г.К. Бельгера - разбор его романа «Дом скитальца». Это произведение по праву является ключевым в творчестве писателя. Поэтому имеет смысл осуществить монографический анализ данного романа.

Посредством эвристической беседы преподаватель направляет студентов на поиск ответов, помогающих им верно понять главные особенности поэтики романа. Приведем примерный список вопросов для эвристической беседы:

1) Какова роль эпиграфа для понимания проблематики романа «Дом скитальца»?

2) Почему главы романа начинаются цитатами из документов, в основном, секретных?

3) Сколько глав в романе? Как и почему они так озаглавлены?

В романе «Дом скитальца» история человека связана с судьбой целого народа. В качестве эпиграфа «Но где мой дом и где рассудок мой?» писатель взял строки Анны Ахматовой. Эпиграф задает тему поиска главными героями своего дома, своей родины.

Студенты объясняют, что главы романа начинаются цитатами из документов. Их функция заключается в том, что они знакомят читателя с депортацией волжских немцев сразу после нападения гитлеровской Германии на СССР. Они были лишены гражданских прав до 1956 года, которым заканчивается действие романа. Сам автор в реальной жизни в шестилетнем возрасте попадает в один из казахских аулов, и поэтому описание действий в романе воспринимается как достоверное (Bel’ger, 2003).

Роман Бельгера состоит из трех глав, названных по именам главных героев - «Давид», «Христьян», «Гарри». В главах воссозданы судьбы трех поколений немецкой семьи Эрлихов-Вальтеров. Далее логично применить такой методический путь анализа, как пообразный, основанный на разборе главных героев произведения. Этот путь анализа позволит студентам разобраться в образах основных героев произведения.

Уместно предложить студентам выступить с сообщениями о главных литературных героях романа. Приведем примерное содержание сообщений.

Студент 1: Один из главных героев романа Давид Эйрлих до войны был военным и членом коммунистической партии. Прямо перед началом войны его сняли с военной службы, так как он был немцем по национальности. Во время депортации Давид Эйрлих теряет жену и сына: его жена - русская по национальности, отказа- лась последовать за ним в ссылку. В Казахстане он в качестве фельдиера работает в амбулатории, которая обслуживает несколько поселков. Но прошлое не отпускает его. Он с тоской вспоминает свое родное село Гнаденфлур.

Между тем, казахские степи, казахский народ постепенно становятся родными и близкими. В романе красочно описана природа на реке Ииим, жилища казахов, их быт и обычаи. Давид после долгих сомнений женится на Олькье Вальтер. Для их детей дом, построенный с помощью соседей-казахов, становится настоящей родиной. История отношений Давида и Олькье сопровождается лиризмом, сердечностью, которые сглаживают тяжелое впечатление от суровых документальных фактов биографии героев романа. Г.К. Бельгер убедительно показывает, как добрый, добросовестный и трудолюбивый Давид становится близким человеком для жителей казахского аула, завоевывает их доверие и авторитет.

Студенты затем переходят к раскрытию образа другого героя

Студент 2: Следуюший документальный материал показан через описание испытаний трудовой армии глазами другого ключевого персонажа - Христьяна, поэта, лиричного, интеллигентного, душевно хрупкого юноши. Детально описанный автором распорядок дня трудармейияа показывает, как невозможно было выжить Христьяну, молодому учителю, или музыканту Оскару, которые, не выдержав тяжельх условий жизни, погибают. Тоска по родному дому, неприкаянность, судьба вечного скитальиа, трагизм бездомья - самый распространённый мотив немецких песен, который воплощается в судьбе Христьяна. Здесь историческая правда депортации немиев соединяется с приемом гротеска при создании художественных образов. Характерно, что образ Давида, а потом и других переселенцев сопровождается песенкой про маленького Гансика, семь долгих лет скитавщегося по чужбине.

Обращаем внимание студентов на такой документальный факт, как карта немецкой автономии в Поволжье, которая чудом сохранилась у Давида. Братья Эрлихи жадно рассматривают карту, и писатель описывает стертую с лица земли республику немцев Поволжья, ее столицу город Энгельс, кантоны, реки, леса, дороги. Братья даже не смеют повесить карту родины на стену, так как опасаются репрессий.

Внимание студентов акцентируется на том, что карта упраздненной немецкой автономии, 
законы Конституции, приказы правительства, газетные вырезки, органично вплетаясь в текст романа, усиливают его историческую, «музейную» сторону, силу его правды. Документальность повествования позволяет автору включать в текст романа образы реальных людей, например, учителя немецкого языка Виктора Кляйна. Информацию о нем можно найти в биобиблиографическом справочнике Бельгера «Российские немецкие писатели». Образ Гарри автобиографичен, прообразом Давида является отец автора Карл Бельгер, которому и посвящен роман. Так озарённая художественным вымыслом правда реальной жизни становится яркой, убедительной и достоверной.

Подводим студентов к анализу следующего главного героя романа, Гарри Вальтера. Он с отличием окончил казахскую школу. Но ему отказано в возможности поступить в вуз. Превосходно говорящий на казахском языке, свободно владеющий русским языком, абитуриент Гарри Вальтер сталкивается в приемной комиссии вуза с враждебным к себе отношением, продиктованным тем, что он немец. Гарри - человек без родины, без паспорта, без гражданских прав. Но его не сломили тяжелые испытания, Гарри становится студентом и получает паспорт.

Следует обратить внимание студентов на транскультурный характер романа Г.К. Бельгера с помощью вопросов - В чем заключается поликультурный характер романа Г.К. Бельгера? Связан ли поликультурный характер романа с художественным документализмом?

Студенты с опорой на текст романа утверждают, что Герольд Бельгер с очевидным мастерством рисует быт казахов, немцев, русских, проявляя глубокие знания национального быта, жизненного уклада, традиций и обычаев. Заметными художественными достоинствами романа выступают инонациональные культурные элементы, а также полиязычие, использование в русской речи немецких и казахских слов и выражений, живость, характерность речи героев. Кроме того, художественная ткань романа включает множество народных песен, поговорок (немецких и казахских), которые отражают преемственность поколений и показывают общечеловеческую значимость выдвинутых писателем проблем (Anan 'eva, 2004; Babkina, 2004; Temirbolat, 2006). Художественный документализм романа выражается также в его поликультурном характере.

Студенты по просьбе преподавателя дают краткие характеристики второстепенным геро- ям рассматриваемого произведения. Используя большое количество документальных фактов, талантливо применяя прием типизации, Г.К. Бельгер показывает судьбы не только российских немцев, но и других советских людей в годы Великой Отечественной войны. В романе воссозданы судьбы многочисленных второстепенных героев, таких как: Газиз, Маруар, Багира, Жарас, Николай Вагнер, Лидия, Есильбай, Иоганн, а также эпизодических персонажей: Яковчук, Фогель, Фрезе, Виктор Кляйн, Виктория и других.

Посредством вопроса «Связан ли хронотоп с художественным документализмом романа?» создаем условия для интерактивного обсуждения, по завершении которого студенты приходят к следующему выводу. Художественный документализм романа «Дом скитальца» проявляется также и на уровне хронотопа. Повествование включает три пространственно-временных плана, каждый из которых тесно связан с образом одного из главных героев. Фабульное время-пространство охватывает тринадцатилетний период жизни главного героя. Действие произведения разворачивается в течение 1941-1954 годов. В романе имеется множество топонимических характеристик, реальных географических названий. Например, события, изображаемые в романе, происходят в казахском ауле Кызыл-ту. Но хронотоп сюжета сложнее, так как не совпадает с фабульным временем-пространством. Повествование в романе кроме линейного событийного ряда включает воспоминания героев, их сны, размышления.

Далее преподаватель приглашает студентов подумать над таким вопросом «В чем заключается многомерность пространственно-временного континуума романа?» Студенты отмечают, что пространственно-временной континуум произведения включает несколько планов: реальный, сказочно-мифологический, исторический. В реальном плане развиваются основные события. Сказочно-мифологический контекст входит в роман через размышления автора и героев. Пространству романа присуща географическая конкретность: автор точно называет населенные пункты, в которых разворачивается сюжетное действие. Исторический план был проанализирован выше, он связан с изображением трагических событий депортации поволжских немцев и их жизни на новой родине.

Важно сформировать у студентов представления об оппозиции, двойственности романа, который построен на основе противопоставления прошлого и настоящего. Настоящее посто- 
янно соотносится автором и героями с прошлым (в тексте часто повторяются слова «теперь» и «тогда»). Казахский аул сравнивается с немецкой деревней. Жизнь главных героев условно делится на два периода: до и после депортации. На уровне хронотопов Давида, Христьяна и Гарри реальное время-пространство нередко сливается с онейрическим временем-пространством. Хронотоп подвижный, так как часто меняет свои границы, он то сужается до пределов судьбы человека, то раздвигается до вселенских масштабов. Оппозиция наблюдается также в пейзажных описаниях. Характеризуя зимний день, который привиделся Христьяну, автор пишет: «Вверху бесновалась стихия, а внизу, под сенью векового леса, царила тишина, звенящая и зловещая» (Bel'ger, 2003: 210).

В ходе разбора романа необходимо подвести студентов к анализу проблематики произведения. Преподаватель предлагает студентам подумать над следующим -отличается ли двойственностью авторская концепция человека в романе? Студенты отвечают на этот вопрос утвердительно. Они отмечают, что оппозиция выражается в интересе писателя к теме жизни и смерти. Произведение содержит идеи о единстве человека и природы. Характеризуя душевное состояние героев, автор обращается к окружающей их действительности, проводит смелые параллели между миром природы и миром человека. Так, Христьян ассоциируется с зимой, Давид - с солнцем. Автор утверждает, что индивидуальное время-пространство является частью пространственно-временного потока жизни природы. Г.К. Бельгер настойчиво поднимает проблему отчуждения, сиротства людей. Практически все его герои одиноки. Одни в силу того, что навсегда утратили родину (Давид, Христьян, Олькье, Жарас и др.), другие - потому что замкнулись в собственном мире (Давид, Христьян). Иногда отчуждение обусловливается «беспамятством» людей (враждебное отношение представителей советской власти к историческому и литературному наследию поволжских немцев).

Студенты убеждаются в том, что многомерность пространственно-временного континуума романа Г.К. Бельгера определяется наличием индивидуального времени-пространства литературных героев. Оно, например, включает реальность, в которой живет Давид Эрлих, и его внутренний мир. Он находится на границе двух миров: реального и онейрического, прошлого и настоящего. «Глухими зимними ночами фельдшера-спецпереселенца Давида Эрлиха, - пишет автор, - в ауле на берегу казахской реки Есиль преследовали тяжкие, как кошмарный сон, видения и воспоминания» (Bel’ger, 2003: 87). Индивидуальное время-пространство Давида вбирает в себя историческое время-пространство. Христьян сравнивает его с Кюстером Дайсом, который жил во времена Екатерины II.

Кроме того, в реальной действительности судьба Давида Эрлиха тесно переплетается с судьбами Жараса, Христьяна, Олькье, Гарри. Их индивидуальные хронотопы образуют единое целое. Так, сирота Жарас является своеобразным воплощением судьбы фельдшера, его прошлого, настоящего и будущего. Как и Давид Эрлих, он одинок и потерял дом, но в конечном итоге находит свое место в жизни. Индивидуальное время-пространство Христьяна соединяется с хронотопом Давида на нескольких уровнях. Во-первых, героев связывает их прошлое. Вовторых, Христьян брат Давида. В-третьих, их индивидуальные время и пространство пересекаются на уровне хронотопа дома. В-четвертых, Христьян выступает как бы нитью, соединяющей Давида с историей и культурой немецкого народа. В-пятых, хронотопы героев сливаются на уровне образа огонька. Рассуждая о судьбе брата, фельдшер задается вопросом о том, как можно сохранить надежду в душе Христьяна. При этом надежда ассоциируется в сознании Давида с теплющимся огоньком, который выступает как символ жизни в видениях Христьяна.

Как известно, имена литературных героев несут в себе большое значение. Семантика имени концентрирует в себе емкую информацию о духовном мире и жизни литературных героев. В завершение анализа романа Бельгера студенты размышляют над вопросом преподавателя - «Какой художественный смысл заключен в именах героев романа Бельгера?»

Студенты говорят, что автор наполняет художественным смыслом имена своих героев. Давид означает «любимый». Имя «Христьян» происходит от слова «христианин». Гарри переводится со староанглийского как «богатый дом». Имена героев, с одной стороны, раскрывают особенности характеров: Давид прагматичен, Христьяну присуща прекрасная память, Гарри отличается талантами и многогранностью натуры. С другой стороны, имена отражают жизненный путь героев. Давид, несмотря ни на что, упорно верит в будущее, поэтому уверенно идет по жизни. Христьян хранит память о прошлом, истории, культуре и традициях немцев. Гарри воплощает будущее, конечную цель тернистого 
пути его народа. Отсюда ясно, что неслучайны названия и расположение частей романа. Первая - «Давид» - символизирует настоящее и стремление в будущее, достичь которое невозможно без памяти о прошлом. Отсюда название второй части - «Христьян». Третья - «Гарри» - выступает своеобразным символом будущего, мечты героев, и шире - человека и общества в целом. Очевидно, резюмируют студенты, что хроно- топы Давида, Христьяна и Гарри воплощают единство прошлого, настоящего и будущего, отражают неотъемлемые части мировосприятия немецкого народа в целом.

В виде обобщения изученного материала следует предложить студентам таблицу, визуально отражающую особенности жанровой природы литературно-художественной автобиографии (таблица 1).

Таблица 1 - Жанровые признаки автобиографического произведения

\begin{tabular}{|c|c|c|}
\hline $\begin{array}{c}\text { Жанровые признаки } \\
\text { автобиографического } \\
\text { произведения }\end{array}$ & $\begin{array}{c}\text { Краткая характеристика жанровых } \\
\text { признаков автобиографического } \\
\text { произведения }\end{array}$ & $\begin{array}{c}\text { Роль жанровых признаков } \\
\text { автобиографического произведения }\end{array}$ \\
\hline автобиографический автор & показ индивидуальной судьбы автора & $\begin{array}{c}\text { образ автобиографического автора } \\
\text { объединяет сюжет произведения }\end{array}$ \\
\hline ретроспективное повествование & воссоздание прошлого & $\begin{array}{c}\text { ретроспективное повествование служит для } \\
\text { выражения авторской рефлексии с позиции } \\
\text { большого жизненного и творческого опыта }\end{array}$ \\
\hline хронологическая \\
последовательность сюжета & $\begin{array}{c}\text { воссоздание духовно-нравственной } \\
\text { эволюции главного героя } \\
\text { сюжета способская последовательность раскрытию этапов } \\
\text { эволюции главного героя и других } \\
\text { персонажей }\end{array}$ \\
\hline
\end{tabular}

\section{Обсуждение}

Методические подходы, описанные выше, успешно прошли апробацию в процессе опытнопедагогической работы, проведенной на базе факультета филологии и мировых языков Казахского национального университета им. аль-Фараби. $\mathrm{B}$ апробации предложенной методики приняли участие 35 студентов.

Важный этап апробации методики анализа произведения - написание студентами эссе. Как известно, рефлексия студентов является показателем их отношения к изучаемой теме. Студенты могут выразить свое понимание поэтики и проблематики произведения в форме эссе. Таким образом, эссе служит для развития литературоведческих компетенций студентов. Подобный взгляд на эссе имеет место в трудах казахстанских ученых. Так, авторы в статье о когнитивной рефлексии в проектной компетенции глубоко раскрыли роль когнитивной рефлексии в формировании проектной компетенции студентов (Mukhatayeva D.I., Zheksembinova A.K., 2019: 4-12).

После изучения романа Г.К. Бельгера «Дом скитальца» студенты получили задание написать эссе на тему «Художественный биографизм в романе Г.К. Бельгера «Дом скитальца». Анализ эссе показал, что студенты проявили интерес к анализу романа Г.К. Бельгера в аспекте соотношения биографического и художественного.

"Чтение насыщенного биографическим материалом романа Г.К. Бельгера дало мне многое. Я поняла, что в литературном произведении могут органично соединяться реальное и вымышленное», - рассуждает автор одного из эссе.

В другом эссе читаем следующее: «Героль $\partial$ Карлович Бельгер прошел трудную и одновременно счастливую школу жизни. Как важно, читая художественный текст, находить в нем приметы реальной жизни, реальных биографических событий».

«Автобиографическое начало в романе Г.К. Бельгера придает этому замечательному произведению убедительность и достоверность, что важно для любого талантливого писателя», убежден автор третьего студенческого эссе.

\section{Заключение}

Таким образом, методика анализа автобиографизма в вузовской аудитории предполагает объемную реконструкцию авторской личности писателя и воссоздание ее субъективных психологических, нравственных, эмоциональных, интеллектуальных и других особенностей. Сту- 
денты должны понять, что писатель стремится пластически изобразить свои внутренние и эмпирически часто не вполне проявленные отношения с реальным миром. Автобиографизм в литературе можно трактовать как воплощенную в произведении точку зрения художника на мир, на себя и на свое место в мире. Такие методические подходы к анализу произведений с ярко выраженным автобиографизмом способствуют успешному литературоведческому развитию студентов, побуждая их к внимательному чтению художественных текстов, что важно для их профессионального становления как филологов.

Эвристический метод способствует проведению практического занятия в интерактивном формате, так как вопросы преподавателя активизируют мышление студентов.

\section{Литература}

1 Барахов В. С. Литературный портрет: Истоки, поэтика, жанр. - Л., 1985. - 150 с.

2 Лейдерман Н.Л., Липовецкий М.Н. (1997). Современная русская литература 1950-1990-е годы. Электронный ресурс. Режим доступа: http://readr.ru/n-leyderman-i-dr-sovremennaya-russkaya-literatura-1950-1990-e-godi.

3 Бронская Л.И. Концепция личности в автобиографической прозе русского зарубежья первой половины XX века. Ставрополь: Изд-во Ставропольского гос. ун-та, 2001. - 120 с.

4 Большев А.О. Исповедально-автобиографическое начало в русской прозе второй половины ХХ века. - СПб., 2002. $-170 \mathrm{c}$

5 Бадиков В.В. По гамбургскому счету. Рассказы, повесть, эссе, воспоминания / Сост. Бадикова В. - Алматы, 2007. $400 \mathrm{c}$.

6 Лежэн Ф. Автобиографический договор. - Париж, 1973. - 124 с.

7 Медарич М. Автобиография / Автобиографизм //Автоинтерпретация. Сборник статей. - СПб. 1998. - 438 с.

8 Нурпеисов А. Мой собрат по перу и друг // Бельгер Г. Тихие беседы на шумных перекрестках. - Алматы: «Арыс», 2001. - C. 5 - 7.

9 Салханова Ж.Х. Художественность и документальность автобиографического текста // Вестник КазНУ им. альФараби, Серия филологическая. - Алматы: Қазақ университеті, 2016. - № 5. - c.78 - 83.

10 Сафронова Л.В. Постмодернистская литература и современное литературоведение Казахстана. - Алматы: КазПНУ им. Абая, 2006. -96 с.

11 Темирболат А.Б. Поэтика литературы. - Алматы: КазНУ им. аль-Фараби, 2011. - 168 с.

12 Демченко А.С. Методические приемы анализа архетипа «Дом» в романах Г. Бельгера // Вестник КазНУ. Серия: Педагогические науки. - Алматы: Қазақ университеті, 2018. - №3(56). - С. 86 - 93.

13 Хуторской А.В. Дидактическая эвристика: Теория и технология креативного обучения. - М.: Изд-во МГУ, 2003. $416 \mathrm{c}$.

14 Занков Л. В. Избранные педагогические труды. - М.: Педагогика, 1990. - 418 с.

15 Давыдов В.В. Проблемы развивающего обучения. - М.: Педагогика, 1986. - 240 с.

16 Бондаревская Е.В. Теория и практика личностно-ориентированного образования. - Ростов-на-Дону: Издательство Ростовского педагогического университета, 2000. - 352c.

17 Селевко Г.К. Педагогические технологии на основе активизации, интенсификации и эффективного управления УВП. - М.: НИИ школьных технологий, 2005. - 288 с.

18 Бельгер Г. Дом скитальца. - Астана: «Аударма», 2003. - 312 с.

19 Ананьева С.В., Бабкина Л.М. Творчество Герольда Бельгера в контексте современного литературного процесса. Алматы, 2004. - 199 с.

20 Темирболат А.Б. Категория хронотопа и темпорального ритма в литературе. - Алматы: КазНУ им.аль-Фараби, 2009. $-199 \mathrm{c}$.

21 Мухатаева Д.И., Жексембинова А.К. Когнитивная рефлексия в проектной компетенции: вопросы планирования социально-педагогического сопровождения деятельности студентов в университетской среде//Вестник КазНУ. Серия: Педагогические науки. - Алматы: Қазақ университеті, 2019. - №1 (58). - С. 4 - 12.

\section{References}

1 Anan'eva S.V., Babkina L.M. (2004). Tvorchestvo Gerol'da Bel'gera v kontekste sovremennogo literaturnogo processa. [Creativity of Herald Belger in the context of the modern literary process]. Almaty. - 199 p. (In Russian)

2 Barahov V.S. (1985). Literaturnyj portret: Istoki, pojetika, zhanr. [Literary portrait: Origins, poetics, genre]. Leningrad. 150 p. (In Russian)

3 Bronskaja L.I. (2001). Koncepcija lichnosti v avtobiograficheskoj proze russkogo zarubezh'ja pervoj poloviny XX veka. [The concept of personality in the autobiographical prose of the Russian foreign countries of the first half of the 20th century]. Stavropol': Izd-vo Stavropol'skogo gos. un-ta. - 120 p. (In Russian)

4 Bol'shev A.O. (2002). Ispovedal'no-avtobiograficheskoe nachalo v russkoj proze vtoroj poloviny XX veka. [Confessional- 
autobiographical beginning in Russian prose of the second half of the XX century]. Sankt-Peterburg. - 170 p. (In Russian)

5 Badikov V.V. Po gamburgskomu schetu. [According to the Hamburg account. Stories, Tale, Essays, Memories] / Sost. Badikova V. - Almaty, 2007. - 400 p. (In Russian)

6 Bondarevskaja E.V. (2000). Teorija i praktika lichnostno-orientirovannogo obrazovanija. [Theory and practice of personality-oriented education]. Rostov-na-Donu: Izdatel'stvo Rostovskogo pedagogicheskogo universiteta. - 352p. (In Russian)

7 Bel'ger G. (2003). Dom skital'ca. [ House of the Wanderer]. Astana: «Audarma». - 312 p. (In Russian)

8 Demchenko A.S. (2018). Metodicheskie priemy analiza arhetipa «Dom» v romanah G. Bel'gera [Methodical methods for the analysis of the archetype "House" in the novels of G. Belger] // Vestnik KazNU. Serija: Pedagogicheskie nauki. - Almaty: Қаzaқ universiteti. - №3(56). - P. 86 - 93. (In Russian)

9 Davydov V.V. (1986). Problemy razvivajushhego obuchenija. [Developmental Learning Issues]. M.: Pedagogika. - 240 p. (In Russian)

10 Hutorskoj A.V. (2003). Didakticheskaja jevristika: Teorija i tehnologija kreativnogo obuchenija. [Didactic heuristics: Theory and technology of creative learning]. M.: Izd-vo MGU. - 416 p. (In Russian)

11 Lejderman N.L., Lipoveckij M.N. (1997). Sovremennaja russkaja literatura 1950-1990-e gody. [Contemporary Russian literature 1950-1990s]. Jelektronnyj resurs. Rezhim dostupa: http://readr.ru/n-leyderman-i-dr-sovremennaya-russkaya-literatura1950-1990-e-godi. (In Russian)

12 Lezhjen F. (1973). Avtobiograficheskij dogovor. [Autobiographical contract]. Parizh, 1973. - 124 p. (In Russian)

13 Medarich M. (1998). Avtobiografija / Avtobiografizm //Avtointerpretacija. Sbornik statej. [Autobiography / Autobiography // Autointerpretation. Digest of articles]. Sankt-Peterburg, 1998. - 438 p. (In Russian)

14 Nurpeisov A. (2001). Moj sobrat po peru i drug // Bel'ger G. Tihie besedy na shumnyh perekrestkah. [My fellow pen and friend // Belger G. Quiet conversations at noisy intersections]. Almaty: «Arys». - P. 5 - 7. (In Russian)

15 Salhanova Zh.H. (2016). Hudozhestvennost' i dokumental'nost' avtobiograficheskogo teksta. [Artistry and documentary of an autobiographical text] // Vestnik KazNU im. al'-Farabi, Serija filologicheskaja. - Almaty: Қаzaқ universiteti. - № 5. - p.78 - 83. (In Russian)

16 Safronova L.V. (2006). Postmodernistskaja literatura i sovremennoe literaturovedenie Kazahstana.[Postmodern literature and modern literary criticism of Kazakhstan]. Almaty: KazPNU im. Abaja. - 96 p. (In Russian)

17 Selevko G.K. (2005). Pedagogicheskie tehnologii na osnove aktivizacii, intensifikacii i jeffektivnogo upravlenija UVP. [Pedagogical technologies based on the activation, intensification and effective management of UVP]. M.: NII shkol'nyh tehnologij. -288 p. (In Russian)

18 Temirbolat A.B. (2011). Pojetika literatury. [Poetics of literature]. Almaty: KazNU im. al'-Farabi. - 168 p. (In Russian)

19 Temirbolat A.B. (2009). Kategorija hronotopa i temporal'nogo ritma v literature. [The category of chronotope and temporal rhythm in the literature]. Almaty: KazNU im.al'-Farabi. - 199 p. (In Russian)

20 Zankov L.V. (1990). Izbrannye pedagogicheskie trudy. [Selected Pedagogical Works]. M.: Pedagogika. - 418 p. (In Russian)

21 Muhataeva D.I., Zheksembinova A.K. (2019). Kognitivnaja refleksija v proektnoj kompetencii: voprosy planirovanija social'no-pedagogicheskogo soprovozhdenija dejatel'nosti studentov v universitetskoj srede//Vestnik KazNU. Serija: Pedagogicheskie nauki. - Almaty: Қаzақ universiteti, 2019. - №1 (58). - 4 - 12 p. (In Russian) 